\title{
An Analysis of Factors Causing Learning Difficulties of Biology Students in the Microbiology Subject, Universitas Negeri Padang
}

\author{
Lasmi Lestari ${ }^{1 *}$ Dwi Hilda Putri ${ }^{1}$ \\ ${ }^{1}$ Dept. of Biology, Faculty of Mathematics and Science (FMIPA), Universitas Negeri Padang, Padang, Indonesia \\ ${ }^{*}$ Corresponding author. Email: lasmilestari95@gmail.com
}

\begin{abstract}
This research was motivated by the learning difficulties experienced by students in the Microbiology Subject that caused their learning competence to be relatively low. This research aims at describing the factors that caused learning difficulties experienced by UNP biology students in the Microbiology Subject. This research was a descriptive research with a qualitative approach. The population in this research was the microbiology lecturers and UNP biology students who had studied the Microbiology Subject. The sample in this research included 2 microbiology lecturers and 4 biology students obtained by a purposive sampling technique. The data collection techniques used were interviews, observation and documentation study. The results showed that students had learning difficulties in the Microbiology Subject that caused by internal and external factors. Internal factors are lack of curiosity, motivation and interest of students in learning microbiology, lack of preparation and readiness of students in presentations and lack of student skills in using foreign language references in the form of text booxes and scientific journals. External factors in the form of learning resources, learning resources owned by students are not appropriate with the subject of the syllabus so students often use reference sources in the form of blogs that have not been validated.
\end{abstract}

Keywords: the Microbiology Subject, learning difficulties, factors causing learning difficulties

\section{INTRODUCTION}

The higher education curriculum is a set of plans and arrangements regarding the objectives, content, and teaching materials as well as the methods used to guide the implementation of activities to achieve higher education goals. The preparation of the curriculum must refer to national standards of higher education [15]. The curriculum for each study program includes the development of intellectual intelligence, noble character, and skills. UniversitasNegeri Padang (UNP) curriculum refers to three government regulations namely Permendikbud No. 49 of 2014 concerning National Standards of Higher Education, Permendikbud No. 73 of 2013 concerning Implementation of the Indonesian National Qualification Framework (KKNI) and Presidential Regulation No. 8 of 2012 concerning the Indonesian National Qualification Framework (KKNI) $[7,8,9,12]$.

KKNI is explained as a framework of the level of qualifications that can express and integrate learning outcomes[10]. Learning outcomes are abilities obtained through internalization of knowledge, attitudes, skills, competencies and accumulation of work experience. The formulation of learning outcomes must refer to the description of learning outcomes according to KKNI. Description or parameters of learning outcomes of undergraduate graduates is equivalent to level 6[8]. The learning achievement parameter for level 6 is being able to apply their field of expertise and utilizing science and technology in their fields in problem solving and being able to adapt. All of these parameters can be measured in the learning process.

The UNP Biology Department offers compulsory and elective courses. One of the compulsory subjects in the Biology Department is microbiology [9]. Microbiology is a branch of biology that studies about microorganisms. Microorganisms are tiny living things (microscopic) that can only be seen with a microscope. Objects of microbiology studies include prokaryotes and viruses. Based on the object of microbiology studies it can be seen that the microbiology course is one of the interesting subjects to study.

Based on FMIPA UNP biology curriculum, it is known that the Microbiology Subjectisa prerequisite subject for several advanced subjects such as biotechnology, microbial genetics, medical microbiology, food microbiology, soil microbiology, industrial microbiology, phytopathology and parasitology. Therefore, students must understand and master the concept of microbiology before studying the advanced subjects.

Understanding the concept of microbiology can be done in the learning process. To understand the concept of microbiology, sometimes various kinds of obstacles are found by students, especially learning difficulties. 
Difficulty of learning is a decrease in learning achievement or the value obtained is not sufficient to limit the criteria set by each tertiary institution [14]. In addition, learning difficulties are also defined as a condition where students cannot learn properly because of certain disorders [6]. So, it can be concluded that learning difficulties are the condition of students who do not study as they should and are not able to get the set value.

Learning difficulties are not only caused by low intelligence but can be caused by non-intelligence factors. Factors that cause students' learning difficulties can come from within students (internal factors) and factors from outside students (external factors) $[2,3,5]$. Internal factors that can cause learning difficulties include talent, interest and motivation. Meanwhile, external factors include the influence of the learning environment, learning resources, and the influence of the teacher [10]. Learning difficulties experienced by students are identified to find out problems both on internal factors and external factors. If students have difficulties in one of them, solutions can be given to those who have learning difficulties.

Tabel 1. UAS grades of UNP biology students in basic microbiology in the January-June 2019 semester

\begin{tabular}{|l|c|c|c|c|}
\hline \multirow{2}{*}{ Grades } & \multicolumn{4}{|c|}{ Class } \\
\cline { 2 - 5 } & A & B & C & D \\
\hline A (85-100) & - & - & - & - \\
\hline B+ (75-79) & - & - & - & - \\
\hline B (70-74) & - & 1 & - & - \\
\hline B-(65-79) & 1 & - & - & - \\
\hline C+(60-64 & 2 & 5 & 2 & 2 \\
\hline C (55-59) & 4 & 5 & 5 & - \\
\hline C-(50-54) & 12 & 9 & 9 & 6 \\
\hline D (40-49) & 15 & 10 & 13 & 21 \\
\hline $\begin{array}{l}\text { E (0-39) } \\
\text { Jumlah } \\
\text { Mahasiswa }\end{array}$ & 37 & 33 & 33 & 38 \\
\hline
\end{tabular}

Suorce: Lecture of basic microbiology (2019)

Based on the facts found in the field, it is known that there are still many UNP biology students who have relatively low basic microbiology scores. This can be seen from the UAS grades of UNP biology students in basic microbiology in the January-June 2019 semester (Table 1). Based on Table 1, it is known that the basic microbiology semester exam scores for UNP biology students are still low at $\leq 70$ or with a range of quality $\mathrm{B}$ to $\mathrm{E}$. The large number of students who have grades between $\mathrm{B}$ to $\mathrm{E}$ is an indication that students are experiencing difficulties in understanding the concept of microbiology. Based on the background of the problem outlined, the authors are interested in conducting further research on, "An Analysis of Factors Causing Learning Difficulties of Biology Students in the Microbiology Subject, Universitas Negeri Padang".

\section{MATERIALS AND METHODS}

This research used some tools such as test tubes, mortar, pippete, volumetric flask, measuring cylinder, beaker glass, spatula, spraying bottle, filter paper, funnel, and distillation set. The materials were ruku-ruku leaves (Ocimum tenuiflorum Linnen) from Batusangkar, nhexane as solvent in extraction, deionised water for steam distillation, sodium sulfate anhydrous for removing water, concentrated sulfuric acid, magnesium powder, cottons, acetic anhydride, concentrated hydrochloric acid, ethanol $70 \%$, aquadest, Wagner reagent, Dragendorff reagent, and Mayer reagent.

\section{RESULT AND DISCUSSION}

The results of this research were obtained from interviews, observations and documentation that have been conducted by researchers.

\subsection{Review}

Interviews aim to get information directly from the source person. In this research the interview used is a guided free interview, where the statement submitted refers to the interview guidelines made, but other questions can arise during the interview process. Based on the results of interviews with a microbiology lecturer, Dr. Irdawati, M. $\mathrm{Si}$., it was known that there were still many biology students who have difficultiesin understanding the concepts and principles of microbiology appropriately. These difficulties can be seen from the advanced lectures (biotechnology), where to achieve learning outcomes (learning outcomes) in thissubject often lecturers must repeat several microbiology topics so that students can connect the material being studied. This was in line with the results of the student interviews which stated that the capital they had in the microbiology subject was not enough to take further subjects.

The results of the interview with Dr. Linda Advinda, M. Kes., it was known that the microbiology lecturing process was carried out with discussion and presentation. The students were assigned to make powerpoints every week. As a reference source, lecturers suggested using references in the form of journals and textbooks, but in general the students used more references from the internet in the form of blogs. According to the students, this was because the references in the form of blogs were easy to find, used simple and easy to understand language, and the students had difficulties in determining keywords to find references other than blogs on the internet 
Based on the results of interviews with the students who had difficulties in learning microbiology it can be concluded: 1) lack of the student curiosity in lectures. The students stated that their curiosity towards microbiology material was very low so that when the lecturing process was completed the students never had the intention to explore the material that had been studied, 2) the lack of motivation and interest of the students in studying the Microbiology Subject. The students mostly expressed their feelings when taking ordinary the Microbiology Subject, this was because the material learned in microbiology was microscopic or could not be seen without using a microscope, 3) the lack of readiness and preparation of the students in studying microbiology. The students stated that they had a low level in understanding the material they would present and what is presented by their friends, 4) the lack of student skills in finding learning resources from foreign references in the form of text books and scientific journals. According to the students some of the learning resources used in lectures were textbooks by Pelczar and the internet in the form of blogs. The students never used foreign references in the form of text books or scientific journals because according to them the language was difficult to understand and their English skills were low.

\subsection{Documentation}

In this research the analyzed documentation was the syllabus, student powerpoint and learning resources used by students. This documentation analysis aims to see the learning achievements that must be achieved by students and what are the obstacles experienced by students in achieving these learning achievements.

Based on the syllabus analysis of the Microbiology Subject for UNP biology students, it was known that the microbiology material that was studied was broadly grouped into 2 namely basic microbiological concept materials and microbiological applications (Table 2). Basic microbiology material that must be studied by students was the history and development of microbiology, bacteria, classification of bacteria, viruses, microbial nutrition, microbial growth, microbial metabolism and symbiotic associations. Meanwhile, the microbiology application materials that must be studied by students included clinical microbiology, food, industry, soil, water, biodegradation and air.

Table 2. Results of Syllabus Analysis

\begin{tabular}{|l|l|l|}
\hline No. & \multicolumn{1}{|c|}{ Materials } & \multicolumn{1}{|c|}{$\begin{array}{c}\text { Group of the } \\
\text { Materials }\end{array}$} \\
\hline 1. & $\begin{array}{l}\text { History and development of } \\
\text { microbiology }\end{array}$ & \multirow{2}{*}{$\begin{array}{l}\text { Basic concepts of } \\
\text { microbiology }\end{array}$} \\
\hline 2. & Bacteria & \\
\hline 3. & Klasifikasibakteri & Virus \\
\hline 5. & Microbial nutrition \\
\hline
\end{tabular}

\begin{tabular}{|c|c|c|}
\hline 6. & Microbial growth & \\
\hline 7. & Microbial metabolism & \\
\hline 8. & Symbiotic Association & \\
\hline 9. & Clinical microbiology & \multirow{7}{*}{$\begin{array}{l}\text { Microbiological } \\
\text { Application }\end{array}$} \\
\hline 10. & Food microbiology & \\
\hline 11. & Industrial Microbiology & \\
\hline 12. & Soil microbiology & \\
\hline 13. & Water microbiology & \\
\hline 14. & $\begin{array}{l}\text { Biodegradation } \\
\text { microbiology }\end{array}$ & \\
\hline 15 . & Air microbiology & \\
\hline No. & Assessment Aspects & Percentage \\
\hline 1. & $\begin{array}{l}\text { The suitability of the material with } \\
\text { the learning outcomes in the } \\
\text { syllabus }\end{array}$ & $33 \%$ \\
\hline 2. & $\begin{array}{l}\text { PowerPoint display is attractive } \\
\text { and easy to read }\end{array}$ & $66,67 \%$ \\
\hline 3. & $\begin{array}{l}\text { The picture presented is clearly } \\
\text { visible and has information }\end{array}$ & $50 \%$ \\
\hline 4. & $\begin{array}{l}\text { Powerpoint has video to support } \\
\text { the material presented }\end{array}$ & $16,67 \%$ \\
\hline 5. & $\begin{array}{l}\text { a. Reference used: } \\
\text { a. Book } \\
\text { b. Google / Web } \\
\text { c. Journal or scientific research }\end{array}$ & $\begin{array}{l}33.33 \% \\
66.67 \% \\
0 \%\end{array}$ \\
\hline
\end{tabular}

After analyzing the syllabus, the researcher then conducted a powerpoint analysis made by the students. Powerpoint analysis was carried out using five criteria: compliance with the learning achievements of the syllabus, display, pictures and videos and references (Table 3 ). Based on the results of the powerpoint analysis it can be seen: 1) the material presented by students was mostly not appropriate with the learning achievements in the syllabus. According to the students this was caused by the textbook being used that did not contain all the material in the syllabus, 2) The display of PowerPoint in general was interesting and easy to read, 3) The images presented in the PowerPoint slide were clear but some were not equipped with picture captions , 4) The students did not attach videos in powerpoint slides, and 5) The references used by the students in making powerpoint mostly came from blogs and textbooks, according tothe students, because of the lack of the students' skills in understanding and searching for 
foreign language references in the form of text book or scientific journals.

In addition to analyzing the syllabus and powerpoint, researchers also conducted textbook analysis. Textbook analysis aims to find out how the feasibility and presentation of the contents of the textbooks to achieve student learning outcomes. In this research the textbooks analyzed were textbooks that are usually used by students in microbiology lectures, namely the book Basic Microbiology by Pelczar. Based on the analysis of textbooks (Table 4) that researchers have done can be seen: 1) the textbooks did not contain all the material in the syllabus so that most of the students use Google alternatives, especially blogs to obtain material related to microbiology material; 2) the textbook display was good but the picture was not colored; 3) textbooks have not improved understanding of concepts and the renewal of science.

Table 3. Results of Student Powerpoint Analysis

\begin{tabular}{|l|l|l|}
\hline No. & Assessment Aspects & Percentage \\
\hline 1. & $\begin{array}{l}\text { The suitability of the material with } \\
\text { the learning outcomes in the } \\
\text { syllabus }\end{array}$ & $33 \%$ \\
\hline 2. & $\begin{array}{l}\text { PowerPoint display is attractive and } \\
\text { easy to read }\end{array}$ & $66,67 \%$ \\
\hline 3. & $\begin{array}{l}\text { The picture presented is clearly } \\
\text { visible and has information }\end{array}$ & $50 \%$ \\
\hline 4. & $\begin{array}{l}\text { Powerpoint has video to support the } \\
\text { material presented }\end{array}$ & $16,67 \%$ \\
\hline 5. & $\begin{array}{l}|c| \text { Reference used: } \\
\text { b. Book } \\
\text { b. Google / Web } \\
\text { c. Journal or scientific research }\end{array}$ & $66.67 \%$ \\
\hline
\end{tabular}

Table 4. Textbook Analysis Results

\begin{tabular}{|c|c|c|c|c|c|}
\hline \multirow[t]{2}{*}{ No. } & \multirow[t]{2}{*}{$\begin{array}{l}\text { Analyzed } \\
\text { aspects }\end{array}$} & \multirow[t]{2}{*}{ Sub Aspects of Analysis } & \multicolumn{3}{|c|}{$\begin{array}{l}\text { Analysis } \\
\text { Results }\end{array}$} \\
\hline & & & B & $\mathbf{S}$ & $\mathbf{K}$ \\
\hline \multirow[t]{2}{*}{. } & \multirow[t]{2}{*}{$\begin{array}{l}\text { 2. C } \\
\text { ompliance } \\
\text { with the } \\
\text { syllabus }\end{array}$} & $\begin{array}{l}\text { a. } \\
\text { aterial in accordance } \\
\text { with the topic on the } \\
\text { syllabus }\end{array}$ & & $\checkmark$ & \\
\hline & & \begin{tabular}{l}
\multicolumn{1}{c}{ b. The } \\
description of the \\
material is in \\
accordance with the \\
indicators of learning \\
outcomes
\end{tabular} & & & $\checkmark$ \\
\hline
\end{tabular}

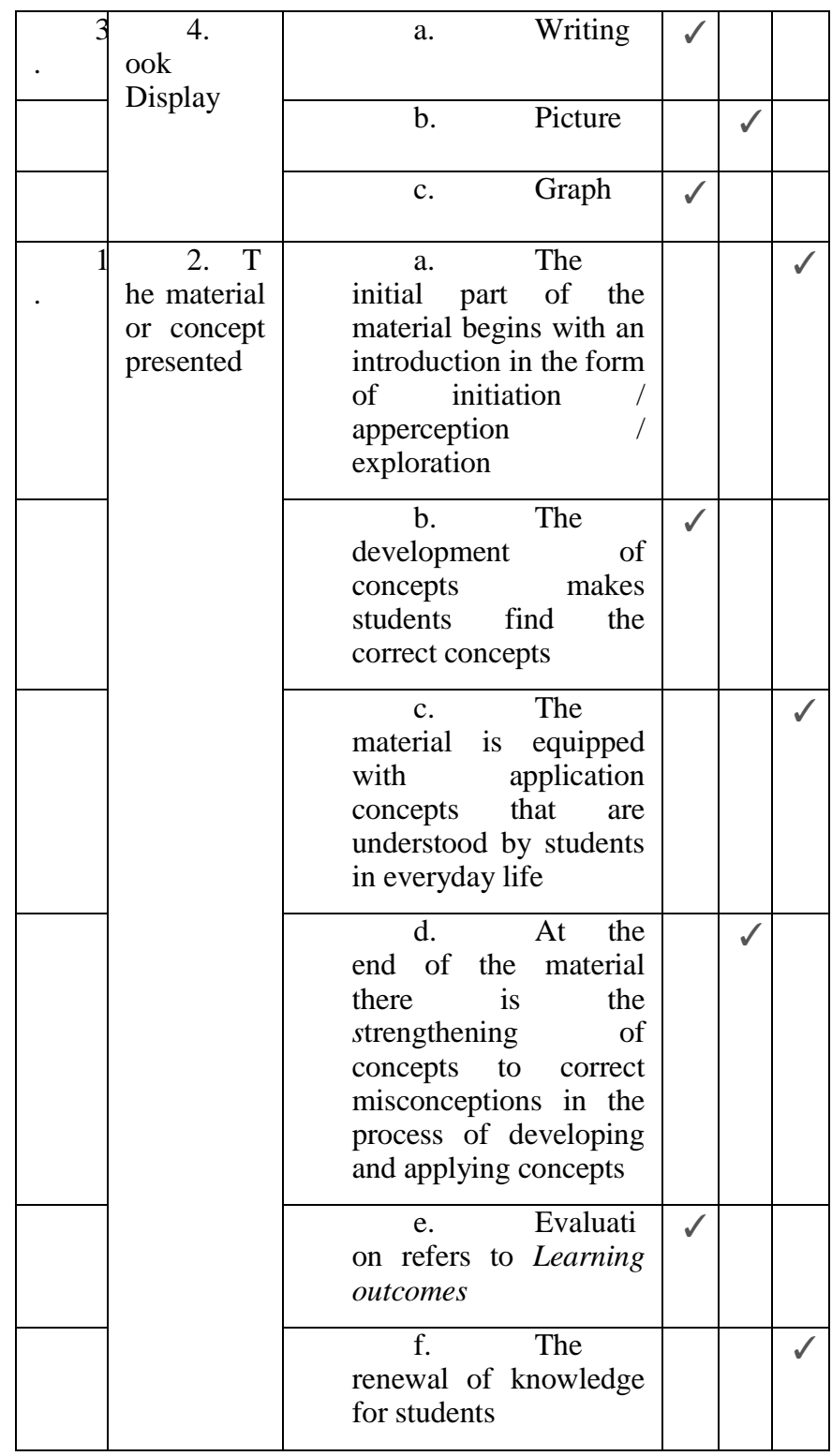

Information:

$\mathrm{B}=\operatorname{good}, \mathrm{S}=$ Medium and $\mathrm{K}=$ Less

\subsection{Observation}

The microbiology lecturing process for UNP biology students was carried out using the lecture and group discussion methods. Based on researchers' observations on the microbiology lecture process, it is known that in the learning process, especially student discussions, lack of preparation in understanding the material to be studied, the group that appeared in the discussion only presented a makeshift material so that the material discussed did not reach the expected learning outcomes.

Furthermore it was also found that students' interest and motivation in the lecturing process was still low, especially the group that did not get the presentation assignment. Most students did not equip themselves from home related material to be studied. This can be seen from some students 
who have just seen the syllabus or material that will be discussed on that day or when the presentation group presents the material. In addition, based on the researchers' observations during the discussion it was seen that only $30 \%$ of students were active in providing suggestions, criticisms, input and questions. Meanwhile, the other $70 \%$ of students are just silent and chatting during discussions.

Based on the combined results of the data that has been obtained in the study, namely from the results of the lecturer and student interviews, documentation and observations made by researchers can be seen that there are 2 factors that influence learning difficulties of UNP biology students in the Microbiology Subject, namely internal factors and external factors. These two factors are described in more detail as follows.

\section{Internal Factors}

Internal factors come from within students. Based on the results that have been found, several internal factors that can influence the learning difficulties of UNP biology students in microbiology courses are lack of curiosity, lack of motivation and interest in students studying microbiology material, lack of readiness and preparation of students in presentations, and lack of student skills in looking for learning resources. Other factors that cause learning difficulties, including the physical condition of students, attitudes in learning, motivation, concentration, how to process teaching materials, exploring learning outcomes, self-confidence and study habits[1].

\section{External Factors}

External factors are factors that come from outside the student self. External factors that influence learning difficulties of UNP biology students in the Mycobiology Subject were learning resources (books). Books are the main source of learning for students. Textbooks are understood as the most widely used teaching tool among all other teaching tools [13]. Books are sources of information that are arranged in a structure and sequence based on a particular field of science. Textbooks are learning tools used in schools and colleges to support a teaching program. In the process of teaching and learning in schools, textbooks can be a guide for teachers and students, namely as the main reference or become additional books. Textbooks are learning tools commonly used in schools and in universities to support a teaching program[4].

Based on the results found, it was known that the learning resources used by students in the lecturing process are textbooks written by Pelczar. Based on powerpoint analysis made by students, it was known that the dominant reference used by students was the web / blog, this was because the material in the textbook was not in accordance with the learning outcomes in the syllabus.

\section{CONCLUSION}

Based on data collection that has been done can be identified two factors that cause students experiencing learning difficulties, namely internal and external factors. Internal factors are lack of curiosity, motivation and interest of students in learning microbiology, lack of preparation and readiness of students in presentations and lack of student skills in using foreign language references in the form of textbooks and scientific journals. External factors in the form of learning resources, learning resources owned by students are not in accordance with the subject of the syllabus so students often use reference sources in the form of blogs that have not been validated. Based on the factors that cause students learning difficulties in the Microbiology Subject, researchers suggest that students be more independent in studying microbiology material with their shortcomings and the need to develop microbiology textbooks in accordance with learning outcomes, interests and learning motivation so that students will consider microbiology as an interesting subject.

\section{REFERENCES}

[1] Aunurrahman. 2014. Belajar dan Pembelajaran. Bandung: CV Alfabeta.

[2] Basiran. 2012. Faktor yang Mempengaruhi Kesulitan dalam Belajar. Jurnal Edukasi. Vol. 7 No. 1.

[3] Caryono, S., dan Suhartono. 2012. Analisis Deskriptif Faktor Penyebab Kesulitan Belajar Mata Pelajaran Matematika di SMA Negeri 8 Purworejo Tahun Pelajaran 2012/2013. Prosiding. ISBN : 978-979-16353-8-7 UNY.

[4] Henno, I., dan Reiska, P. 2010. Difficulty of Texts in Upper-Secondary School Biology TextbookUsing Concept Maps for Analyzing Students New knowledge. University of Tallin: Estonia.

[5] Huda, A. I., F. Harahap, S. Edi. 2017. Analysis of Biological Difficulties in Studying Tissue Culture at State University of Medan Indonesia. International Journal of Humanities Social Sciences and Education (IJHSSE).Volume 4, Issue 11 .

[6] Ismail. 2016. Diagnosis Kesulitan Belajar Siswa dalam Pembelajaran Aktif di Sekolah. Jurnal Edukasi. Vol 2 Nomor 1.

[7] Permendikbud Nomor 49 Tahun 2014 Standar Nasional Pendidikan Tinggi.

[8] Permendikbud Nomor 73 Tahun 2013 Tentang Penerapan Kerangka Kualifikasi Nasional Indonesia (KKNI).

[9] Peraturan Presiden Republik Indonesia Nomor 8 Tahun 2012 Tentang Kerangka Kualifikasi Nasional Pendidikan (KNNI).

[10] Rahmadani, W., F, Harahap., T, Gultom. 2017. Analisis Faktor Kesulitan Belajar Siswa Materi 
Bioteknologi di SMA se-Kota Medan. Jurnal Pendidikan Biologi. Vol 6. No. 2.

[11] Rektorat UNP. 2015. Buku Pedoman Akademik Universitas Negeri Padang. Padang: UNP Press.

[12] . 2018. Rencana Strategi (Renstra) Universitas Negeri Padang 2015-2018. Padang. UNP Press.

[13] Rosyadi.A.R. 2008. Menjadi Penulis Profesional. Bogor: Ghalia Indonesia.

[14] Syah, M. 2006. Psikologi Belajar. Jakarta : Raja Grafindo Persad.

[15] Undang-Undang No. 12 Tahun 2012 Tentang Pendidikan Tinggi. 